\title{
G. Cardol e.a. (red.), Jongensbesnijdenis bezien vanuit mensenrechtelijk perspectief ${ }^{*}$
}

\author{
Prof. mr. J.C.J. Dute*
}

Jongensbesnijdenis wordt wereldwijd op grote schaal toegepast. In Nederland worden elk jaar tussen de 10.000 en 15.000 jongens besneden - enkele dagen na de geboorte, na een aantal maanden of net voor de pubertijd - meestal om godsdienstige redenen. De ingreep is niet onomstreden. Vanuit mensenrechtelijk perspectief rijst de vraag hoe de godsdienstvrijheid van de ouders zich verhoudt tot de autonomie en het recht op lichamelijke integriteit van het kind. Het is deze vraag die in deze bundel centraal staat. De bundel kent vijf bijdragen (van de hand van Vlaardingerbroek, Van Dijk, De Blois, Cardol en Van der Wieken), gelardeerd met een casus en een viertal standpunten (onder andere van de KNMG en de Kinderombudsman). Het geheel wordt afgesloten met een epiloog (Forder).

In zijn bijdrage stelt Vlaardingerbroek dat 'meisjesbesnijdenis streng verboden moet blijven en dat de besnijdenis van jongens alleen kan worden toegestaan als die wordt uitgevoerd door een geschoolde en ervaren arts en (...) in een kliniek (...).' Verder vindt hij 'het beter als de jongen zelf in vrijheid met zijn besnijdenis kan instemmen' (p. 18). Het onderscheid tussen meisjes- en jongensbesnijdenis wordt in een prikkelend betoog onderuitgehaald door Van Dijk. Hij stelt dat vrouwenbesnijdenis verschillende, ook milde varianten kent. Volgens hem zijn de meest voorkomende vormen van vrouwenbesnijdenis zelfs minder ingrijpend dan de meest voorko-

* G. Cardol, T. Veerman \& A. Wolthuis (red.), Jongensbesnijdenis bezien vanuit mensenrechtelijk perspectief, Leiden: Stichting NJCM-Boekerij 2015 (ISBN 978-90-6750-058-6)

** Jos Dute is lid van het College voor de Rechten van de Mens, hoogleraar gezondheidsrecht aan de Faculteit der Rechtsgeleerdheid van de Radboud Universiteit en redacteur van dit tijdschrift. mende vormen van jongensbesnijdenis. $\mathrm{Nu}$ vrouwenbesnijdenis in al haar varianten is verboden, zou dit ook moeten gelden voor jongensbesnijdenis, zo vindt hij. Op de vraag waarom niet ook de omgekeerde redenering zou kunnen worden gevolgd (milde vormen van vrouwenbesnijdenis uitzonderen van het verbod) gaat Van Dijk niet in.

De Blois stelt dat 'collectieve structuren zoals gezinnen en godsdienstige gemeenschappen net als het individu aanspraak kunnen maken op bescherming tegen de staat, ook waar het om de uitoefening van traditionele religieuze praktijken gaat' (p. 52). Hij zet zich daarmee af tegen een mensenrechtelijke benadering die het individuele zelfbeschikkingsrecht centraal stelt. Mijns inziens is dit een vruchteloze redenering. Bij mensenrechten staat het individu nu eenmaal centraal. De Blois beroept zich ook op de medische voordelen van jongensbesnijdenis. Nog daargelaten of die voordelen er wel zijn - evidence hiervoor ontbreekt en andere auteurs, zoals Van Dijk, wijzen juist op de (soms ernstige) negatieve lichamelijke en geestelijke gevolgen - vind ik dit een oneigenlijk argument: de besnijdenis is immers geen op gezondheidsoverwegingen gestoelde, preventieve ingreep, maar een religieuze handeling. Maar dan moet een pleidooi voor jongensbesnijdenis ook niet worden vertroebeld met medische argumenten. Cardol beschouwt jongensbesnijdenis als een onomkeerbare handeling die alleen mag worden toegepast als het kind daarmee kan instemmen. Besnijdenis van nog niet wilsbekwame jongens acht hij in strijd met de 'harde kern van de menselijke waardigheid', te weten 'de mogelijkheid tot ontwikkeling en ontplooiing van het individu' (p. 64). Besnijdenis mag daarom pas op latere leeftijd plaatsvinden. Uitstellen van de besnijdenis tot de leeftijd 
van 12 of 16 jaar is vanuit de optiek van het joodse geloof evenwel geen optie, zo stelt Van der Wieken. De besnijdenis dient immers plaats te vinden op de achtste dag. Zijn bijdrage ontspoort in mijn visie als hij stelt dat bij elke opvoeding op alle mogelijke manieren aanslagen worden gepleegd op de fysieke en psychische integriteit van het wilsonbekwame kind' (p. 79), waarbij hij wijst op verkeerde voeding, roken, alcohol en drugs tijdens de zwangerschap, te weinig liefde en aandacht, scheidingen, verkeerde schoolkeuzes, piercings, enzovoorts. Hij schuwt zelfs de vergelijking met abortus niet: als abortus ('de zwaarste schending van de integriteit') is toegestaan, waarom 'een geringe, in het geheel nietlevensbedreigende ingreep aan een pasgeboren jongen' dan niet, zo vraagt hij zich af (p. 81). Wie zo argumenteert, zet zichzelf buitenspel.

Alles bijeengenomen geeft de bundel een goed beeld van de achtergronden van, de relevante overwegingen bij en de standpunten van waaruit de problematiek van de jongensbesnijdenis kan worden benaderd (door Forder gekwalificeerd als een 'loopgravenoorlog, waarbij de verdedigers van de verschillende standpunten volstrekt verdeeld blijven, zonder uitzicht op enige beweging,, p. 91). Niet alle invalshoeken komen aan de orde. De samenstellers geven dat ook ruiterlijk toe. In de inleiding geven zij aan vergeefs te hebben geprobeerd ook de islamitische en de strafrechtelijke invalshoek erbij te betrekken.

Mijns inziens wordt ook een gezondheidsrechtelijke benadering node gemist. Vanuit dat oogpunt staat de godsdienst- en de opvoedingsvrijheid van de ouders tegenover de autonomie en de lichamelijke integriteit van het jonge kind. Dit spanningsveld kennen we ook van de vraag of de poliovaccinatie verplicht zou moeten worden gesteld. In Nederland is daar nooit voor gekozen, en terecht. De afdwingbaarheid van een dergelijke verplichting is problematisch en het risico bestaat dat de betrokkenen onbereikbaar worden voor alternatieve maatregelen. Om dezelfde (pragmatische) redenen is naar mijn oordeel ook een verbod of anderszins een wettelijke regeling van de besnijdenis (bijvoorbeeld een leeftijdsgrens) geen optie. Voorkomen moet worden dat de besnijdenis 'ondergronds' gaat. Verder moet hoe dan ook worden vastgehouden aan een veilige en verantwoorde uitvoering. 